\title{
On (Mis-)Conceptions of Culture as a Vehicle of Business Success: Singapore Chinese Investment Strategies after Failing in China
}

\author{
Heidi Dahles
}

Received: 2 September 2006 / Accepted: 19 April 2007 /

Published online: 5 June 2007

(C) Springer Science + Business Media B.V. 2007

\begin{abstract}
The focus of this paper is on the strategies applied by Singapore Chinese businesses upon failing in their China business ventures. It has been argued that both the increase in Singapore ventures into China and the failures are due to either cultural issues (misconceptions of 'shared ethnicity') or economic factors (differences in economic practices). Singapore businesspeople apply inclusive strategies combining Western management styles with allegedly Chinese ways of doing business in order to reduce the risk involved with investments across national borders into China. Though largely successful, this strategy entails its own risks. Based on a number of case studies, this paper discusses the diverse business experiences of Singapore Chinese entrepreneurs in China, their response to business failure and their strategies to relocate their transnational business ventures.
\end{abstract}

Keywords Singapore Chinese businesses · Small and medium enterprises (SMEs) · China business ventures $\cdot$ Business failures $\cdot$ Cultural affinity

\section{Introduction}

Doing business in mainland China is a popular topic in current management books and expat manuals boasting of tips and tricks to ensure successful business deals for businesspeople who enter China with great hopes and expectations. This literature is produced particularly to guide Western businesspeople in their China venture as it is implicitly or explicitly understood that Chinese business culture strongly contrasts with its Western counterpart. Inspired by Hofstede's ${ }^{1}$ analysis of cultural differences, it is claimed that Western capitalist market cultures characterized by individualism,

${ }^{1}$ Geert Hofstede, Allemaal andersdenkenden. Omgaan met cultuurverschillen (Amsterdam: Contact, 1995).

H. Dahles $(\bowtie)$

Department of Culture, Organization and Management of the Vrije Universiteit Amsterdam, Amsterdam, The Netherlands

e-mail: h.dahles@fsw.vu.nl 
rationality and secularism meet with collectivism, familism and Confucianism in China. The upsurge of foreign direct investment in China during the 1990s and the emergence of more and more Sino-foreign joint ventures have raised concerns about management, organisational culture and corporate identity. From a Western perspective, many publications testify to the different-ness of China and the Chinese in general and of doing business in China in particular. $^{2}$

However hard Western businesspeople may try to acquire an understanding of cultural norms and values to be successful in China, the accumulation of a good network to provide access to Chinese bureaucratic power is difficult to accomplish without the relevant connections built on trust and patronage. The lessons for Western managers to learn are manifold. They have to dismiss the idea that trust has to be based on calculation of economic costs and benefits and on shared business strategies and management styles. They also have to dismiss the idea that affectionbased trust has to be rejected as 'unprofessional'. They have to accept that formal contracts are no guarantee for the implementation of an agreement and that patronage relations are discreditable and remnants of an era prior to the advent of capitalism and the modern nation state. Recent analyses of organisational relationships in the global economy have claimed that in international ventures a growth of networks can be witnessed, networks which are based on ethnic affiliation, and that cultural responsiveness constitutes a business strategy of increasing importance. ${ }^{3}$ In this respect it seems obvious that Westerners face a structural disadvantage vis-à-vis some of their Asian competitors when it comes to establish rapport with the Chinese.

Conversely, management gurus like Kotkin ${ }^{4}$ have identified ethnic ties — allegedly more affection-based than other forms of social relations - as the success formula of Asian businesses. Ethnic Chinese businesses in particular, organised in 'bamboonetworks, 5 are regarded as the spearheads of Asia's economic growth as well as a major global force. As the story goes, the large Chinese diaspora living in Southeast Asia and in ethnic Chinese communities scattered all over the world enjoys special

\footnotetext{
${ }^{2}$ Bernard Wilpert and Sophia Yen Scharpf, "Intercultural Management - Joint Ventures in the People's Republic of China," International Journal of Psychology 25:5/6 (1990), 643-665. Jia Xianfeng, Creating Sino-Foreign Equity Joint Ventures. Technology Transfer: Negotiation, Product Selection and Localization (Enschede: Print 2000, 1993); Robert P. Weller, "Divided Market Cultures in China. Gender, Enterprise, and Religion," in Robert W. Hefner, ed., Market Cultures. Society and Morality in the New Asian Capitalisms (Boulder [Colorado]: Westview, 1998), 78-103; Christopher Buckley, "How a Revolution Becomes a Dinner Party. Stratification, Mobility and the New Rich in Urban China", in Michael Pinches, ed., Culture and Privilege in Capitalist Asia (London/New York: Routledge, 1999), 208-229; Dough Guthrie, Dragon in a Three-Piece Suit. The Emergence of Capitalism in China (Princeton: Princeton University Press, 1999); Li J.T., Anne S. Tsui and Elizabeth Weldon, eds., Management and Organizations in the Chinese Context (Houndmills, Basingstoke, Hampshire: Macmillan Press, 2000); Thomas Gold, Doug Guthrie and David Wank, eds., Social Connections in China. Institutions, Culture, and the Changing Nature of Guanxi (Cambridge: Cambridge University Press, 2002).

${ }^{3}$ Willem Koot, Peter Leisink and Paul Verweel, eds., Organizational Relationships in the Networking Age. The Dynamics of Identity Formation and Bonding (Cheltenham: Edgar Elgar, 2003).

${ }^{4}$ Joel Kotkin, Tribes: How Race, Religion, and Identity Determine Success in the New Global Economy (New York: Random House, 1993).

${ }^{5}$ Murray Weidenbaum and Samuel Hughes, The Bamboo Network: How Expatriate Chinese Entrepreneurs Are Creating a New Economic Superpower in Asia (New York: The Free Press, 1996). 
privileges when it comes to business ventures in China. After all, being descendents of Chinese migrants, they not only look Chinese, but they can also be expected to speak Mandarin or at least one of the many Chinese dialects, maintain connections with their ancestral village and be familiar with or at least sensitive to Chinese ways of doing business. Indeed, the image of the networking, family-based, flexible overseas Chinese business has become a trope in the literature on transnational relations in contemporary Southeast Asia ${ }^{6}$ and beyond. ${ }^{7}$ Coupled with the capacity for hard work and trust based on blood ties or ritual kinship, Chinese business networks seem to epitomise Chinese capitalism and seem to have engendered the economic success of the overseas Chinese where others failed. ${ }^{8}$

One of the ethnic Chinese communities that should prove this case in point is the city-state of Singapore, the only place outside of Greater China where the Chinese constitute the majority of the population. In the late 1980s, with China re-entering the world economy and Singapore craving new markets to overcome economic recession, the Singapore government was among the first to invest in China. Since the establishment of diplomatic relations between Singapore and China in 1990, there has been a rapid increase in the number of Singaporeans visiting China for the purposes of both ancestor worship and economic investments ${ }^{9}$. Presently, Singapore is among the largest foreign investors in China, while China is among the most important countries for Singapore's investments abroad ${ }^{10}$.

\footnotetext{
${ }^{6}$ Cf. Chan Kwok Bun, "State, Economy and Culture: Reflections on the Chinese Business Networks", in Chan Kwok Bun, ed., Chinese Business Networks: State, Economy and Culture (Singapore: Prentice Hall and Nordic Institute of Asian Studies, 2000), 1-13; Neil M. Coe, Philip F. Kelly and Kris Olds, "Globalization, Transnationalism, and the Asia-Pacific," in Jamie Peck and Henry Wai-chung Yeung, eds., Remaking the Global Economy. Economic-Geographical Perspective (London: Sage, 2003), 45-60; Leo Douw, "The Chinese Sojourner Discourse," in Leo Douw, Cen Huang and Michael R. Godley, eds., Qiaoxiang Ties: Interdisciplinary Approaches to 'Cultural Capitalism' in South China. (London/New York: Kegan Paul, 1999), 22-44; E. Terence Gomez, and Michael Hsiao Hsin-Huang, "Introduction: Chinese Business Research in Southeast Asia," in E. Terence Gomez and Michael Hsiao Hsin-Huang, eds., Chinese Business in South-East Asia: Contesting Cultural Explanations, Researching Entrepreneurship (London and New York: Routledge Curzon, 2004), 1-37; Gordon S. Redding, The Spirit of Chinese Capitalism (Berlin, New York: Walter de Gruyter, 1990); Leo Suryadinata, ed., Ethnic Chinese as Southeast Asians (Singapore: ISEAS, 1997); Henry Yeung Wai-chung and Kris Olds, "Globalizing Chinese Business Firms: Where Are They Coming From, Where Are They Heading?." in Henry Yeung Wai-chung and Kris Olds, eds., Globalization of Chinese Business Firms (Houndmills, Basingstoke: Macmillan Press, 2000), 1-30.

${ }^{7}$ Cf. Aihwa Ong, Flexible Citizenship. The Cultural Logics of Transnationality (Durham and London: Dukes University Press, 1999). Aihwa Ong and Donald M. Nonini, eds., Ungrounded Empires. The Cultural Politics of Modern Chinese Transnationalism (New York/London: Routledge, 1997).

${ }^{8}$ Gordon S. Redding, The Spirit of Chinese Capitalism (Berlin, New York: Walter de Gruyter, 1990).

${ }^{9}$ Paul J. Bolt, China and Southeast Asia's Ethnic Chinese. State and Diaspora in Contemporary Asia (Westport, Conn./London: Praeger, 2000); Kuah Khun Eng, "Anxi Connection: Ancestor Worship as Moral-Cultural Capital," in Leo Douw, Cen Huang and Michael R. Godley, eds., Qiaoxiang Ties: Interdisciplinary Approaches to 'Cultural Capitalism' in South China (London/New York: Kegan Paul, 1999), 143-157; Tan Nan Sy, The Political Economy of Singapore's Regionalisation Policy (Singapore: Department of Economics and Statistics, National University of Singapore, 1996).

${ }^{10}$ Paul J. Bolt, China and Southeast Asia's Ethnic Chinese. State and Diaspora in Contemporary Asia (Westport, Conn./London: Praeger, 2000), 135-136; Sree Kumar, Sharon Siddique and Yuwa HedrickWong, Mind the Gaps: Singapore Business in China (Singapore: ISEAS, 2005).
} 
However, there is also an increase in the number of business failures of which no records are kept. Many Singapore Chinese businesspeople_-including the Singapore government as the largest entrepreneur in the city-state-have learned the hard way that their mainland China counterparts do not necessarily subscribe to the image of Singaporeans as fellow Chinese and treat them as foreigners. Conversely, Hong Kong Chinese companies are rather successful in their mainland China ventures. Being pioneers in mainland investments when China opened its borders to foreign investments, Hong Kong entrepreneurs showed flexibility, patience, local sensitivity and long-term perspectives instead of a quest for quick profits in their business ventures. Although they had their share of failures in China, Hong Kong (and Macao) entrepreneurs had a competitive advantage over other investors from East and Southeast Asia as they were regarded not as "'foreigners' but tong bao compatriots - and could thus contribute to national modernization in a way that was less threatening than assistance from capitalists ...". " Singaporeans, entertaining the idea of a shared ethnicity and 'Chinese culture' but being defined as both foreigners and capitalists in mainland China, obviously fell into the trap of regarding the Chinese as one homogeneous category.

In this paper, Singaporean business failures in China will be investigated in terms of the consequences that Singaporean businesspeople draw from their experience and the ways in which they respond to business failure. How do they cope with the discovery that their alleged cultural advantage vis-à-vis other investors in Chinatheir self-declared dual identity between China and the West - turned out to be a misjudgement of how the Chinese conceive of them? What effects does this revelation have for both their self-image and their image of the mainland Chinese? And how do these revised images affect their views of the future location of their transborder business ventures? In contrast to the recently published study by Kumar, Siddique and Hedrick-Wong, ${ }^{12}$ which analyses the factors that contributed to the success of both large and small Singapore businesses in China and the lessons that these businesses put to use to improve their competitive position there, this paper focuses on small businesses that - upon suffering bankruptcy-pull out of China. Based on a number of case studies, the focus is on the ways in which Singapore Chinese entrepreneurs redefine and relocate their business ventures after leaving China.

This paper is structured as follows: After elaborating on the current theoretical debate addressing issues of cultural versus capitalist motives of ethnic Chinese business ventures into China and a brief portrayal of the development of Singapore investments in China from the late 1980s, the paper proceeds with a brief description of the available database. In the following section, the empirical findings are presented, featuring a number of selected case studies. In the concluding section, some theoretical thoughts will be developed for further investigation.

\footnotetext{
${ }^{11}$ Alan Smart and Josephine Smart, "Failures and Strategies of Hong Kong Firms in China: An Ethnographic Perspective", in Henry Yeung Wai-chung and Kris Olds, eds., Globalization of Chinese Business Firms (Houndmills, Basingstoke: Macmillan Press, 2000), 244-271.

12 Sree Kumar, Sharon Siddique and Yuwa Hedrick-Wong, Mind the Gaps: Singapore Business in China (Singapore: ISEAS, 2005).
}

Springer 


\section{Ethnic Chinese Transborder Ventures: A Theoretical Perspective}

Chinese capitalism has been described in terms of a 'network capitalism' characterised by both hierarchical relationships within the family and a system of reciprocal relationships known as guanxi (good connections). Chinese business ventures consisting of independent firms loosely structured in multi-firm business groups ${ }^{13}$ or 'bamboo networks ${ }^{14}$ have been traced to a Confucian value system that presumably emphasises trust and responsibilities towards the lineage. ${ }^{15}$ It has been argued that this centrality of the family as a fundamental unit of social and economic organisation gives the ethnic Chinese their sense of Chineseness. ${ }^{16}$ The central argument of this 'culturalist' approach is that the institutions, norms and practices of ethnic Chinese businesspeople have facilitated the growth of their enterprises and the emergence of ethnic business networks - extending into mainland China.

It has, however, been questioned whether many ethnic Chinese businesspeople from Southeast Asia share a bond based on a common ethnic identity in general and with the Chinese in China in particular. The homogenising assumptions of the culturalist approach ignore the experiences of Chinese communities and individual Chinese entrepreneurs under specific and widely differing economic and political conditions. The approach that stresses 'profit seeking' as a main motive for transnational ventures focuses on how global and local economic organisation presents the Chinese with opportunities. ${ }^{17}$ Mutual interest instead of common ethnic identity seems to characterise successful cooperative efforts among Chinese businesses across national borders. ${ }^{18}$

In this 'culture versus capitalism' debate, the impact of political power on economic actors is lacking. A political-economy perspective focuses on culture as an

\footnotetext{
${ }^{13}$ Robert W. Hefner, ed., Market Cultures. Society and Morality in the New Asian Capitalisms (Boulder [Colorado]: Westview, 1998).

${ }^{14}$ Murray Weidenbaum and Samuel Hughes, The Bamboo Network: How Expatriate Chinese Entrepreneurs Are Creating a New Economic Superpower in Asia (New York: The Free Press, 1996).

${ }^{15}$ Cf. Francis Fukuyama, Trust: The Social Virtues and the Creation of Prosperity (New York: Free Press, 1995); Joel Kotkin, Tribes: How Race, Religion, and Identity Determine Success in the New Global Economy (New York: Random House, 1993); Gordon S. Redding, The Spirit of Chinese Capitalism (Berlin, New York: Walter de Gruyter, 1990).

${ }^{16}$ Cf. Henry Yeung Wai-chung and Kris Olds, eds., Globalization of Chinese Business Firms (Houndmills, Basingstoke: Macmillan Press, 2000).

${ }^{17}$ E. Terence Gomez, Chinese Business in Malaysia: Accumulation, Accommodation and Ascendance (Richmond, Surrey: Curzon Press, 1999). J. Victor Jesudason, Ethnicity and the Economy: The State, Chinese Business, and the Multinationals in Malaysia (Singapore: Oxford University Press, 1989). Isabelle Thireau and Hua Linshan, "Overseas Chinese Entrepreneurs: Cultural Norms as Resources and Constraints", in Leo Douw, Cen Huang and Michael R. Godley, eds., Qiaoxiang Ties. Interdisciplinary Approaches to 'Cultural Capitalism' in South China (London/New York: Kegan Paul, 1999), 187-216.

${ }^{18}$ Michael R. Godley, "The Moral Economy of Profit: Diaspora Capitalism and the Future of China”, in Leo Douw, Cen Huang and Michael R. Godley, eds., Qiaoxiang Ties: Interdisciplinary Approaches to 'Cultural Capitalism' in South China (London/New York: Kegan Paul, 1999), 267-305. Hodder, Rupert A., Merchant Princes of the East: Cultural Delusions, Economic Success and the Overseas Chinese in Southeast Asia (Chichester: John Wiley, 1996).
} 
instrument for the protection of material and political interests. ${ }^{19}$ This approach contests essentialist arguments that culture, shared identities and value systems determine ethnic business activity. Culture and ethnicity are social phenomena that can be manipulated by governments, businesspeople and community organisations in the pursuit of their own goals. In present-day Asia, states are directly involved in economic decisions taken by private entrepreneurs in their country. They do not shy away from far-going interventions such as forced savings, tax policies to attract (foreign) investments, restricting capital outflow, and repressing interest rates and by so doing, shaping financial market activity, providing logistics infrastructure and targeting service-rich sophisticated manufacturing, which strongly influences the pattern of service sector location and growth. ${ }^{20}$ Singapore, in particular, is described as a 'developmental' state, as the government itself ventured into profit-oriented projects acting as the city-state's main economic agent for a number of decades. A developmental state, according to Leftwich, can be defined as a state "whose politics have concentrated sufficient power, autonomy and capacity at the centre to shape, pursue and encourage the achievement of explicit developmental objectives ...". ${ }^{21}$ Under these conditions, government patronage is of great importance for domestic entrepreneurs whose economic success is closely intertwined with state-orchestrated privileges allocated to specific (ethnic) groups.

The three different perspectives are brought together in Hamilton's institutional approach which claims that the organisation of business firms is largely shaped by institutional structures, business networks being the most characteristic example. ${ }^{22}$ Business networks are useful institutional means of implementing co-operative strategies and enhancing "institutional thickness" 23 in any business system. In the context of Chinese business networks, 'institutional thickness' can be generally represented by the strong cultural and social embeddedness of business networks in personal relationships (guanxi), high levels of personal and social interaction among actors in these networks, collective representation through trade and commercial associations and informal business groupings, state patronage and the quest for mutual benefits. ${ }^{24}$

\footnotetext{
${ }^{19}$ E. Terence Gomez, "Introduction: Political Business in East Asia," in E. Terence Gomez, ed., Political Business in East Asia (London/New York: Routledge, 2002), 1-33; E. Terence Gomez and Michael Hsiao Hsin-Huang, eds., Chinese Business in South-East Asia: Contesting Cultural Explanations, Researching Entrepreneurship (London and New York: Routledge Curzon, 2004).

${ }^{20}$ Kevin O'Connor and Thomas A. Hutton, "Producer Services in the Asia Pacific Region: An Overview of Research Issues," Asia Pacific Viewpoint [Special Issue: Producer Services in the Asia Pacific Region. Editor: Kevin O'Connor] 39:2 (1998), 139-143.

${ }^{21}$ Adrian Leftwich, "Bringing Politics Back In: Towards a Model of the Developmental State". Journal of Developmental Studies 31:3 (1995), 400.

${ }^{22}$ Gary G. Hamilton, ed., Asian Business Networks (Berlin: Walter de Gruyter, 1996). Gary G. Hamilton, "Reciprocity and Control: The Organization of Chinese Family-Owned Conglomerates," in Henry Yeung Wai-chung and Kris Olds, eds., Globalization of Chinese Business Firms (Houndmills, Basingstoke: Macmillan Press, 2000), 55-74.

${ }^{23}$ Arif Amin and Nigel Thrift as cited by Yeung and Olds, eds., Globalization of Chinese Business Firms (Houndmills, Basingstoke: Macmillan Press, 2000), 15.

${ }^{24}$ Ibid., 15-16.

Springer
} 
Chinese family firms may still play an important role in the business networks as providers of resources, such as the capital for business start-ups, hands-on training and good connections. While Chinese families may have lost their position as overall capital providers to institutes of formal education providing professional training and to governments intervening in markets and controlling economic assets, they have also become part of larger networks of loosely connected sets of firms. ${ }^{25}$ Therefore, the role of inter- and intra-family linkages as providers of network relations must not be underestimated - whether based on affective ties or mutual benefit. While maintaining the inclusive perspective of the institutional approach, $\mathrm{Ng}^{26}$ argues in favour of a historical viewpoint on capital assets of the ethnic Chinese. He identifies a shift from family and ethnic linkages in the pre-independence period to more profit-oriented assets and, finally, state-sponsored benefits for Singaporean businesspeople venturing abroad. Considering this generational shift, one may wonder whether the young generation of entrepreneurs also draws on the traditional ethnicbased ties that characterise the investment patterns favoured by the older generations and leverage these into a new form of social capital as a distinct source of competitive advantage.

Literature addressing (ethnic) Chinese business ventures emphasises the significance of social capital in cooperation and coalition building. ${ }^{27}$ This applies in particular to small and medium enterprises that regard flexible and informal networking as normal business practice. "Chinese business tends to be conducted through a series of personalized networks based on friendship and trust which are given substance by long term relationships and reputation of trustworthiness and reliability, rather than in the open marketplace or in an institutional framework". ${ }^{28}$ Ethnic Chinese businesspeople accumulate social capital by maintaining membership in a number of partly overlapping networks. "There is not one Chinese diaspora network but many, based initially on things like language groups, clan associations or place of origin, or alternatively on old school or university friends, but given substance over time by business association. Business people are often members of more than one network and can pass members from one network to another... The strength of these networks is also their capacity for extension to new members in

\footnotetext{
${ }^{25}$ Ichiro Numazaki, "Chinese Business Enterprise as Inter-family Partnership: A Comparison with the Japanese Case," in Chan Kwok Bun, ed., Chinese Business Networks: State, Economy and Culture (Singapore: Prentice Hall and Nordic Institute of Asian Studies, 2000), 172.

${ }^{26} \mathrm{Ng}$ Beoy Kui, "The Changing Role of Ethnic SMEs in Economic Restructuring in Singapore: From Two-legged Policy to Three-legged Strategy," in Leo Suryadinata, ed., Ethnic Chinese in Singapore and Malaysia: a Dialogue between Tradition and Modernity (Singapore: Times Academic Press, 2002).

${ }^{27}$ Heidi Dahles, "Transborder Business: The 'Capital' Input in Singapore Enterprises Venturing into ASEAN and Beyond," Sojourn Journal of Social Issues in Southeast Asia 17:2 (2002): 249-273. Heidi Dahles, "Venturing Across Borders. Investment Strategies of Singapore-Chinese Entrepreneurs in Mainland China," Asian Journal of Social Sciences 32:1 (2004), 19-41. Heidi Dahles, "Culture, Capitalism and Political Entrepreneurship: Transnational business ventures of the Singapore-Chinese in China," Culture and Organization 11:2 (2005), 45-58.

${ }^{28}$ Noel Tracy and Constance Lever-Tracy, "A New Alliance for Profit: China's Local Industries and the Chinese Diaspora," in Thomas Menkhoff and Solvay Gerke, eds., Chinese Entrepreneurship and Asian Business Networks (London and New York: Routledge Curzon, 2002), 65-83.
} 
new places". ${ }^{29}$ This strategy of networking enables (ethnic) Chinese businesspeople to evade failing vertical linkages, such as bureaucratic obstacles, by forming horizontal coalitions based on guanxi relationships. Guanxi-based personal trust is an expansive and inclusive principle providing the 'institutional thickness' that characterises (ethnic) Chinese business networks in a globalising business environment. ${ }^{30}$ This perspective provides a framework for the analysis of the practices applied by Singapore Chinese businesspeople venturing into mainland China markets and their failure.

\section{Singapore Business in Mainland China}

Following the establishment of diplomatic relations between Singapore and China in 1990, there has been a rapid increase in capital investments in China, Singapore being among the largest investors. In China, the economic reform and modernisation programme since 1979, including the designation of Special Economic Zones (SEZs) and 'open cities' in the provinces of Guangdong and Fujian, has attracted Chinese overseas investors who had their ancestral roots there. ${ }^{31}$ Before 1994, over 80 percent of all Singaporean investment projects were situated in the provinces of Guandong and Fujian, where most Chinese Singaporeans originated. These investment projects were initiated primarily by private Singaporean companies and were relatively small-scale. ${ }^{32}$ Starting in the mid-1990s, ventures into China were organised by the Singapore government which led consortia of government-led companies (GLCs) and local companies further north to Wuxi, Suzhou, and other places in Zhejiang, Henan and Sichuan provinces. ${ }^{33}$ These missions included smalland medium-scale enterprises as part of the government schemes promoting this sector and creating an 'external wing' of the Singapore economy. ${ }^{34}$ More recently,

\footnotetext{
${ }^{29}$ Ibid.; cf. also Tan Chai-Zhi and Henry Yeung Wai-chung, "The Internationalization of Singaporean Firms into China: Entry Modes and Investment Strategies," in Henry Yeung Wai-chung and Kris Olds, eds., Globalization of Chinese Business Firms (Houndmills, Basingstoke: Macmillan Press, 2000), 220243.

${ }^{30}$ Chan Kwok Bun and Tong Chee Kiong, "Singaporean Chinese Doing Business in China," in Chan Kwok Bun, ed., Chinese Business Networks: State, Economy and Culture (Singapore: Prentice Hall and Nordic Institute of Asian Studies, 2000), 71-85.

${ }^{31}$ Tan Chai-Zhi and Henry Yeung Wai-chung, "The Internationalization of Singaporean Firms into China: Entry Modes and Investment Strategies," in Henry Yeung Wai-chung and Kris Olds, eds., Globalization of Chinese Business Firms (Houndmills, Basingstoke: Macmillan Press, 2000).

${ }^{32}$ Chan Kwok Bun and Tong Chee Kiong, "Singaporean Chinese Doing Business in China," in Chan Kwok Bun, ed., Chinese Business Networks: State, Economy and Culture (Singapore: Prentice Hall and Nordic Institute of Asian Studies, 2000), 72.

${ }^{33}$ Chan Kwok Bun, "State, Economy and Culture: Reflections on the Chinese Business Networks", in Chan Kwok Bun, ed., Chinese Business Networks: State, Economy and Culture (Singapore: Prentice Hall and Nordic Institute of Asian Studies, 2000); Tan Nan Sy, The Political Economy of Singapore's Regionalisation Policy (Singapore: Department of Economics and Statistics, National University of Singapore, 1996).

${ }^{34} \mathrm{Ng}$ Beoy Kui, "The changing role of ethnic SMEs in economic restructuring in Singapore: From toelegged policy to three-legged strategy," in Leo Suryadinata, ed., Ethnic Chinese in Singapore and Malaysia: a Dialogue between Tradition and Modernity (Singapore: Times Academic Press, 2002), 262. 
the expansion of investments by GLCs has been to more peripheral areas in China. Investors are moving away from the older SEZs and into newer areas such as Yunnan and Sichuan, as the less developed inland provinces offer attractive concessions. ${ }^{35}$ However, Singaporean private firms, both large and small, prefer to concentrate their investments in the coastal areas rather than in China's interior. ${ }^{36}$

The type and scale of investments have also changed. In the initial period, funds were directed primarily towards real estate development, food processing and manufacturing. These traditional investment sectors are still popular among smaller enterprises. ${ }^{37}$ The services sector has become a new and rather diversified area for investment among large private and public enterprises targeting leisure and recreation, the tourism industry, environmental protection, warehousing, finance, logistics, communications and information technology. Singaporean GLCs in joint ventures with third-country firms or Chinese state investment agencies are involved in massive projects, such as the development of ports, industrial parks and infrastructural projects that require huge injections of financial capital. ${ }^{38}$

While for the latter investments the concept of political entrepreneurship has been coined to describe the role of the Singapore government as being one of the most important institutional forces behind Singapore investments in China, ${ }^{39}$ small Singapore companies benefited from family relationships that had been maintained through a long period of political hostility between China and Singapore. Once the establishment of diplomatic relations between the two countries relaxed travel restrictions, increasing numbers of Singaporeans returned for purposes of ancestor worship as well as economic investments that contributed needed developmental capital. ${ }^{40}$ In addition to capitalist considerations - the promise of quick and large profits - affinity with the village where one's family originated and a shared 'Chinese' identity contributed to the interest taken by ethnic Chinese businesspeople to invest in China. ${ }^{41}$ In addition to being a strategy for overcoming economic recession and counteracting political insecurity in Southeast Asia, Singapore's China policy must also be regarded as a balancing act to establish an identity of its own,

\footnotetext{
${ }^{35}$ Chan Kwok Bun and Tong Chee Kiong, "Singaporean Chinese Doing Business in China," in Chan Kwok Bun, ed., Chinese Business Networks: State, Economy and Culture (Singapore: Prentice Hall and Nordic Institute of Asian Studies, 2000), 71-85.

${ }^{36}$ Paul J. Bolt, China and Southeast Asia's Ethnic Chinese. State and Diaspora in Contemporary Asia (Westport, Conn./London: Praeger, 2000), 139.

${ }^{37}$ Ibid., 138.

${ }^{38}$ Chan Kwok Bun and Tong Chee Kiong, "Singaporean Chinese Doing Business in China," in Chan Kwok Bun, ed., Chinese Business Networks: State, Economy and Culture (Singapore: Prentice Hall and Nordic Institute of Asian Studies, 2000), 71-85.
}

39 Tan Chai-Zhi and Henry Yeung Wai-chung, "The Internationalization of Singaporean Firms into China: Entry Modes and Investment Strategies," in Henry Yeung Wai-chung and Kris Olds, eds., Globalization of Chinese Business Firms (Houndmills, Basingstoke: Macmillan Press, 2000), 239.

${ }^{40}$ Kuah Khun Eng, “Anxi Connection: Ancestor Worship as Moral-Cultural Capital,” in Leo Douw, Cen Huang and Michael R. Godley, eds., Qiaoxiang Ties: Interdisciplinary Approaches to 'Cultural Capitalism' in South China (London/New York: Kegan Paul, 1999), 143.

${ }^{41}$ Leo Douw, "The Chinese Sojourner Discourse," in Leo Douw, Cen Huang and Michael R. Godley, eds., Qiaoxiang Ties: Interdisciplinary Approaches to 'Cultural Capitalism' in South China. (London/New York: Kegan Paul, 1999), 22-44. 
often juggling conflicting forces of Westernisation (holding the promise of economic prosperity) and Sinification (holding the promise of cultural authenticity). Singapore Chinese businesspeople seem to benefit from their dual identity as they can exploit the ethnic advantage by strategically playing up their Chinese identity when dealing with businesspeople in mainland China. At the same time, their being different is what makes them attractive business partners for the Chinese, as they represent the successful Asian model of modernisation without Westernisation ${ }^{42}$-at least, this is what the Singaporean corporate sector, the government and a few political analysts thought.

Investments in mainland China by large and small businesses certainly generated considerable returns for Singapore entrepreneurs and for the city-state, ${ }^{43}$ but the investments also came with certain risks and failed to yield the huge profits that many Singaporean entrepreneurs had dreamt of when setting out to enter China. The most infamous example of a business failure is provided by the Singapore government with its much publicised Suzhou project. This project aimed at the development of a 70-square-kilometre industrial township in Suzhou, dubbed 'Singapore II' ${ }^{44}$ This project, which started in 1993, received government support at both provincial and national levels. It was agreed to and signed by the national governments of Singapore and China to transfer knowledge in economic management and public administration from Singapore to China, granting Singapore a 65 -percent stake in the project. The total investments in the project were estimated to reach US\$ 30 billion. ${ }^{45}$ In 1997, the project, which had already attracted private investors from Western and Asian countries, ran into problems which were caused by conflicts between the joint Chinese-Singaporean management and by competition from a rival industrial park established by the Suzhou government adjacent to the Singaporean venture. The loss on this project-which the Singapore government handed over to the Chinese in 2001 — was estimated at about US\$ 90 million. $^{46}$

\section{The Database}

Underlying this paper is a database of 56 case studies of Singaporean small and medium companies in the manufacturing (18), trade and distribution (24), retail (2), agriculture (1) and services sectors (11). The largest of these companies counts 209 employees. The vast majority, however, have between 10 and 20 staff. Most of these companies (52) are owned by ethnic Chinese people and managed by their owners (49). The case studies were established with the purpose of gaining insight into intraand inter-ethnic relations in cross-border business ventures, whether long-standing or

\footnotetext{
${ }^{42}$ Chan Kwok Bun and Tong Chee Kiong, "Singaporean Chinese Doing Business in China," in Chan Kwok Bun, ed., Chinese Business Networks: State, Economy and Culture (Singapore: Prentice Hall and Nordic Institute of Asian Studies, 2000).

${ }^{43}$ Cf. Sree Kumar, Sharon Siddique and Yuwa Hedrick-Wong, Mind the Gaps: Singapore Business in China (Singapore: ISEAS, 2005).

${ }^{44}$ Paul J. Bolt, China and Southeast Asia's Ethnic Chinese. State and Diaspora in Contemporary Asia (Westport, Conn./London: Praeger, 2000), 139.

${ }^{45}$ Ibid., 140.

${ }^{46}$ Ibid., 140.

Springer
} 
recently established. Twenty-four of the case studies include investments in mainland China and 8 cherish plans to take their business to China, without having taken concrete steps yet. Of the 24 companies with business experience in China, 9 discussed their business failures and subsequent re-location of foreign ventures with the researcher (see Table 1 below). It should be noted that the database was not established with the purpose of addressing the issue of China ventures and business failures; these themes were not brought up by the researcher but emerged spontaneously during the interviews. The numbers offered here are not empirically representative; they merely describe random occurrence in the database.

The research methods applied may be characterised in terms of organisational ethnography which refers to a way of doing fieldwork. Fieldwork is a long-term involvement with the people under study with the aim of obtaining an in-depth understanding of the ways in which they construct their world and give meaning to their lives. In attempting to establish the case studies in Singapore, however, the researcher often encountered the problem of being denied long-term participation in everyday organisational practice and, as a consequence, failed to reach beyond the public face and front-stage behaviour that organisational members present to outsiders. In these cases, the researcher limited herself to obtaining ethno-data, i.e. answers to open interview questions. ${ }^{47}$ Only a few case studies represent an in-depth ethnographic description compiled from a number of lengthy conversations with the manager-owners in their 'natural habitat' and with people from their private and business network, resulting in a thick description ${ }^{48}$ of what I prefer to term 'business-life-history'. This is a biographical method which focuses on the chronology of critical events and decisions in the life of an entrepreneur that describe his or her career as a businessperson.

In a context where firms are unstable, business start-ups quickly end in bankruptcy and mergers and acquisitions are pertinent, as is the case of many Singapore small and medium-sized enterprises (SMEs), an ethnographic-historical approach focusing on organisations as basic units of research would be an unrewarding venture. The purpose of the ethnographic case studies I collected was to obtain an in-depth understanding of the ways in which Singaporean entrepreneurs establish business coalitions with foreign companies within and across Singaporean borders and how these coalitions are intertwined with the politics of identity that are characteristic of the intra- and inter-state relations in East and Southeast Asia. In the next section, the findings from both approaches-single-interview cases and business-life-histories-will be presented.

\section{Coping with Failure-Learning from Failure?}

In this section, Singapore business ventures into mainland China will be discussed in terms of the strategies applied by the owners/managers to start and maintain their

\footnotetext{
${ }^{47}$ Heidi Dahles, "Organizational Ethnography," in Stewart R. Clegg and John A. Bailey, eds., International Encyclopedia of Organization Studies (London: Sage, 2006 - forthcoming).

${ }^{48}$ Clifford Geertz, The Interpretation of Cultures. Selected Essays by Clifford Geertz (New York: Basic Books, 1973).
} 
Table 1 Overview of China ventures and business failures

\begin{tabular}{|c|c|c|c|c|c|}
\hline No. & $\begin{array}{l}\text { Company name } \\
\text { (Pseudonym) }\end{array}$ & Sector & $\begin{array}{l}\text { China } \\
\text { business } \\
\text { ventures }\end{array}$ & Reason for failure & $\begin{array}{l}\text { Relocation } \\
\text { to }\end{array}$ \\
\hline 1 & Seco-tech & $\begin{array}{c}\text { Business-to- } \\
\text { business } \\
\text { services }\end{array}$ & Subsidiary & & \\
\hline 2 & Hermes Controls & Trade & Planned & & \\
\hline 3 & Kuno Electronics & $\begin{array}{l}\text { Retail and } \\
\text { wholesale }\end{array}$ & Planned & & \\
\hline 4 & $\begin{array}{l}\text { YingYang Holdings } \\
\text { [case 1] }\end{array}$ & $\begin{array}{l}\text { Business-to- } \\
\text { business } \\
\text { services }\end{array}$ & Failure & Chinese too Westernised & Malaysia \\
\hline 5 & Flashlight & Manufacturing & Planned & & \\
\hline 6 & Tindale & $\begin{array}{l}\text { Business-to- } \\
\text { business } \\
\text { services }\end{array}$ & Planned & & \\
\hline 7 & SHP Industries & Manufacturing & Subsidiary & & \\
\hline 8 & CGG & Trade & Representative & & \\
\hline 9 & Spears & Trade & Representative & & \\
\hline 10 & Orosy Technology & Trade & Representative & & \\
\hline 11 & Omega Asia & Trade & Representative & & \\
\hline 12 & Lichfeld Technology & Manufacturing & Subsidiary & & \\
\hline 13 & $\begin{array}{l}\text { COM-Elect Special } \\
\text { Products }\end{array}$ & Manufacturing & Planned & & \\
\hline 14 & Hafmo Engineering & Manufacturing & Representative & & \\
\hline 15 & $\begin{array}{l}\text { NOB } \\
\text { Agricultural\&Chemical }\end{array}$ & Agriculture & Subsidiary & & \\
\hline 16 & Borax Office & $\begin{array}{c}\text { Business-to- } \\
\text { business } \\
\text { services }\end{array}$ & Representative & & \\
\hline 17 & Track Enterprises & $\begin{array}{l}\text { Retail and } \\
\text { wholesale }\end{array}$ & Planned & & \\
\hline 18 & Brightstar & Manufacturing & Failure & Chinese favouritism & $\begin{array}{l}\text { Middle } \\
\text { East, } \\
\text { Australia }\end{array}$ \\
\hline 19 & Wings Asia & Manufacturing & Planned & & \\
\hline 20 & $\begin{array}{l}\text { Principal Refrigeration } \\
\text { \& Airconditionning }\end{array}$ & Trade & Failure & $\begin{array}{l}\text { Cheated by distant kin in } \\
\text { China }\end{array}$ & Malaysia \\
\hline 21 & Wang Sound & Trade & Failure & $\begin{array}{c}\text { Mainland Chinese are not } \\
\text { loyal to Singaporeans }\end{array}$ & Malaysia \\
\hline 22 & Emanuelle & Retail & Planned & & \\
\hline 23 & KHG Trading & Trade & Representative & & \\
\hline 24 & Kock Guan Farming & Trade & Subsidiary & & \\
\hline 25 & Templex [case 3] & Trade & Failure & $\begin{array}{l}\text { Chinese partner went } \\
\text { broke }\end{array}$ & Malaysia \\
\hline 26 & Sparkle & Manufacturing & Representative & & \\
\hline 27 & Quick Services & Trade & Representative & & \\
\hline 28 & Two Brothers & Manufacturing & Failure & 'Tricky business' & India \\
\hline 29 & Commobile & Trade & Subsidiary & & \\
\hline 30 & $\begin{array}{l}\text { Green Apple IT } \\
\text { Solutions [case 2) }\end{array}$ & $\begin{array}{l}\text { Business-to- } \\
\text { business } \\
\text { services }\end{array}$ & Failure & $\begin{array}{l}\text { Problems with corrupt } \\
\text { government }\end{array}$ & $\begin{array}{l}\text { Malaysia, } \\
\text { US }\end{array}$ \\
\hline 31 & Hay Logistics & $\begin{array}{l}\text { Business-to- } \\
\text { business } \\
\text { services }\end{array}$ & Failure & Lack of guanxi & $\begin{array}{l}\text { Malaysia, } \\
\text { Australia }\end{array}$ \\
\hline 32 & PC Mobile & $\begin{array}{c}\text { Business-to- } \\
\text { business } \\
\text { services }\end{array}$ & Failure & $\begin{array}{l}\text { Lack of overall } \\
\text { understanding of China }\end{array}$ & UK \\
\hline
\end{tabular}


enterprises in China. The preferential use of personal resources such as family ties and diverse forms of ethnic affiliation (expressed through lineage, dialect group, hometown associations, etc.) and the intermingling of economic and sentimental reasons for doing business in China are among the characteristics of a strategy which 'culturalist' scholars describe as 'typically Chinese'. This strategy describes the way in which first-generation Chinese established shop in Singapore and went about their trade in the early years of colonial Singapore and into the 1960 s. ${ }^{49}$ Conversely, the establishment of the modern city-state brought about a myriad of new business strategies such as subcontracting and other cooperative relations with either GLCs or foreign multinational corporations (MNCs) and with foreign friends and acquaintances recruited during overseas education. ${ }^{50}$ The use of both government patronage and personal assets - which may be labelled the 'Singapore way' - reflects the rather adaptive way of doing business of second- and third-generation Singapore entrepreneurs and may be described in terms of pursuing new opportunities and mutual interests - as the 'capitalist' scholars argue. ${ }^{51}$ Often, the allegedly 'typical Chinese' and 'capitalist' strategies are combined together to be used selectively, constituting a mixed approach within a specific context. The analysis below will identify differences in the ways in which Singaporean businesspeople who use both strategies separately and in a mixed version respond to business failure in China. For each of the three strategies, one exemplary case will be presented in 'boxes' to illustrate how the response to business failure is related to the business strategy involved.

\section{The ‘Typically Chinese’ Way}

Trading with China and, in particular, importing Chinese goods to and from one's ancestral village, is the 'traditional way' of doing business with the homeland and characteristic of many first-generation ethnic Chinese firms in Singapore. Few of these first-generation Chinese are still at the helm of their companies; most have been taken over by the next generation(s) or have perished for lack of a successor. With the next generation in charge, the companies often undergo far-reaching adjustments in terms of management styles, business practices and market orientation. Also, the products of these firms diversify. First-generation ethnic Chinese were looking for markets from which to buy traditional Chinese products for import to Singapore; these products were then traded on the local market where there was a substantial demand for authentic Chinese consumer goods. The second

\footnotetext{
${ }^{49}$ Heidi Dahles, "Transborder Business: The 'Capital' Input in Singapore Enterprises Venturing into ASEAN and Beyond,” Sojourn Journal of Social Issues in Southeast Asia 17:2 (2002): 249-273.

${ }^{50}$ Ibid.; Heidi Dahles, "Venturing Across Borders. Investment Strategies of Singapore-Chinese Entrepreneurs in Mainland China," Asian Journal of Social Sciences 32:1 (2004), 19-41. Heidi Dahles, "Culture, Capitalism and Political Entrepreneurship: Transnational Business Ventures of the SingaporeChinese in China," Culture and Organization 11:2 (2005), 45-58.

51 These scholars deny that Chinese entrepreneurs are driven by any consideration other than profit maximisation and rational choice in their business behaviour, see E. Terence Gomez, Chinese Business in Malaysia: Accumulation, Accommodation and Ascendance (Richmond, Surrey: Curzon Press, 1999), 6-14.
} 
generation is more inclined to look for markets in China where they can sell their products from Singapore while, at the same time, they diversify and expand their business beyond China and Singapore. The number of trading firms in my database (see Table 1) is still large (12 of the 32 companies).

When asked about the reasons for venturing into mainland China, the small and medium-scale entrepreneurs produced answers that showed a mix of calculation and sentiment. The majority referred to the economic opportunities that this huge country seemed to offer, but they also mentioned the advantages of having relatives in China, speaking the language and their familiarity with and the pleasure taken in 'Chinese ways of doing business'. One of my third-generation Chinese informants, John Lea, director of the manufacturing firm 'Wings Asia', firmly believes that his proficiency in the Cantonese language will provide him with an excellent start for his planned business venture into China, although he lacks any connections whatsoever.

The entrepreneurs in this category who experienced business failure pulled out of China never to return, but they did not lose faith in the basic strategy they used to establish cross-border business coalitions, i.e. the strategy of building on family and ethnic relations. As Case 1 below illustrates, it is in these kinds of relations that sentiments and emotions are invested, regardless of where kin and co-ethnics are located. The betrayal by distant kin in China is blamed on the weakness of these blood ties, not on the failure of kin and ethnic groups as providers of trust. Hence, instead of persuading businesspeople to shift their cross-border business strategies from kin/ethnic-based to 'rationalist' approaches, kin and ethnic groups become even more important for doing business. The shift is from defining one's identity as rooted in mainland China (before it turned communist), to locating one's roots in colonial Southeast Asia under British rule.

\section{Case 1: Failure of the 'Chinese Way'}

Principal Refrigerating \& Air conditioning ${ }^{52}$

... was established in 1965 by the brother of its present owner as a trading firm in household items. The business changed into a successful exporting firm in refrigeration spare parts. Principal R\&A is a family business owned by Mr Luh, a Singaporean Chinese, and managed by his Malaysian Chinese wife. The firm is embedded in the Luh's extended family network: forty members are involved in the business as branch managers, staff or associates. Principal R\&A has Singapore as its home base and offices in Kuala Lumpur and Johore Bahru (Malaysia). These offices are managed by Mrs Luh's brothers.

Principal R\&A was one of the first small entrepreneurs from Singapore to enter China as early as 1988. The Luh couple established business links with distant kin in Hong Kong who ran a few companies across the border. The Luhs entrusted them with the capital to start trade offices in mainland China. The Hong Kong relatives took the money to China but invested it in their own mainland manufacturing

\footnotetext{
${ }^{52}$ All names of companies and interviewees cited in this text are pseudonyms. The researchers involved in establishing the database agreed with the respondents not to reveal their and their firm's identity.

型 Springer
} 
businesses that suffered bankruptcy. After this failure, the Luhs decided to play it safe. They consolidated their Singapore business and started to expand their Malaysian branch offices through Mrs Luh's close kin. "One has to be careful doing business in China”, says Mrs Luh, "in Malaysia with close relatives, we don't expect bad surprises". Although Mrs Luh is aware of the different position of the ethnic Chinese in Singapore and Malaysia, she denies that there are any cultural differences between the Singaporean and Malaysian Chinese. After all, she remarked, "Malaysia and Singapore used to be a British colony".

(Interview 2002).

\section{Doing Business the 'Singapore Way'}

For decades, the Singapore government invited foreign multinational corporations to invest and locate their regional head offices in Singapore. When the government started to promote the establishment of an 'external wing' of the Singapore economy, these MNCs obtained the role of intermediary for introducing Singaporean entrepreneurs to foreign markets. The preferred position of Singapore businesspeople as subcontractors of foreign MNCs provided crucial assets to venture beyond Singapore. Basically, it was a risk-avoidance strategy that allowed small companies to ride the waves of the expansion drift of their main clients by benefiting from their local knowledge, networks and contacts with the foreign state agencies. Recently, Singapore Chinese companies working for large Japanese or Western MNCs were more or less forced to do business across the border when their clients decided to cut costs by outsourcing or relocating some of their production units to low-payment countries in the region. This applies for example to Kuno Electronics, a Japanese subsidiary in Singapore, which is preparing for a business venture into China as ordered by the Tokyo head office. The Tokyo management believes that their company will be more successful in China if represented by their Singaporean staff due to 'more friendly connections'. There are also examples of companies that emerged after their owners (former MNC employees or subcontractors) were introduced to foreign markets by their former employers or clients.

Another business strategy that offers risk-avoidance when venturing into China is participation in government missions. This strategy emerged with the political entrepreneurship of the Singapore developmental state and has been most prominent in traditional service sectors such as construction and transportation, distribution, and warehousing. Entrepreneurs in these sectors benefited from the large-scale public projects initiated by government agencies such as the Port of Singapore Authority, the Mass Rapid Transport Corporation, and the Housing Development Board (HDB). Later on, other economic sectors, such as computer hardware and software, business services, and biotechnology, also became important for government-initiated projects. Having established a good reputation in government circles, these entrepreneurs were invited by state agencies to join government missions abroad. These patterns can also be discerned among Singaporean SMEs venturing into China, as Case 2 below illustrates.

Cultural affinity may stimulate investments, but capitalist considerations certainly constitute the major reason for the 'new' businesspeople to venture into China. Instead of diasporic affiliation with the (imagined) homeland, Singapore government 
protection, the promise of a huge market and cheap labour provide the motives for venturing into China. However, many Singaporean businesspeople also assigned a particular business zest to the mainland China business partners. Chinese efficiency, resourcefulness and respect for Singaporeans play a decisive role for businesspeople from the city-state when seeking cooperation with mainland Chinese partners. "The Chinese have a mechanically efficient mind," said one of our informants. "They have four seasons and always have to think one year ahead," added another Singaporean entrepreneur. "China realises that there are things we can learn from each other and that we can be equal partners. It's not about who is more superior, it's about business...", commented a third informant.

\section{Case 2: Government sponsorship}

\section{Green Apple IT Solutions}

Henry Chan Hock Seng, the owner and manager of Green Apple IT Solutions, a dotcom firm situated in Singapore's China town, was born in 1965 as the second child and only son of a Singaporean Chinese real estate agent. Henry obtained an engineering degree from NTU Singapore in 1990 and an MBA diploma from a polytechnic-turned-university in Perth (Australia) two years later. Upon his return to Singapore in 1992, he held several jobs with foreign MNCs and domestic companies before venturing out on his own. His business in the information technology sector did well for a few months until the Asian Crisis hit. He was forced to lay off his four employees and hired himself out to foreign and local multinational corporations on a project basis.

Only two years later, ambitions were soaring again as Singaporean enterprises were lured into entering the global market by their entrepreneurial government. In 1999, Henry was invited to join a government-sponsored trade mission to China owing to his father's connections with the HDB involved in industrial estate development in China. This mission resulted in Henry's involvement in a few projects. With his name on the list of participants of the HDB mission, foreign and domestic firms with an interest in China investments approached him with job offers.

Having established a network of potential clients, Henry opened a Shanghai branch of the Green Apple. At first, this branch did reasonably well, but soon encountered problems with clients from local state-owned enterprises. In 2003 Henry considered pulling out of Shanghai, but postponed this decision as another business venture into Beijing was pending.

In 2004, when the Green Apple was taken over by another Singaporean IT firm, its Shanghai branch split off from the Singaporean parent company and joined forces with a local IT firm. This joint venture did reasonably well, but cooperation between Singaporean and mainland Chinese managers did not run smoothly. The biggest bone of contention between the partners was the 'overhead', as Henry euphemistically labelled the bribes that he refused to pay. As his Shanghai counterpart was better equipped to deal with the Chinese government and the Chinese market, Henry became more of a silent partner leaving most of the management to his local counterpart. After four years, Henry's Beijing venture still had not been approved by 
the Chinese authorities. Henry felt bitter about Chinese bureaucracy, which he characterised as hostile and corrupt. Eventually, Henry lost interest in China. His new international joint venture in Kuala Lumpur opened exciting new avenues to the European and American markets. ${ }^{53}$

In the personal network of young entrepreneurs in Singapore, connections established during their education abroad (which implies that they are English educated), with former employers and colleagues, and professional associations (in contrast to traditional Chinese hometown associations) play a rather prominent role. These connections directly or indirectly provide a vehicle for launching business across the border into Southeast Asia, China and the Asia-Pacific, often with the ultimate aim of starting a successful venture in the United States. Henry Chan, who is introduced in Case 2, provides a good example of this shift. In 2003, his first firm, Green Apple IT Solutions, which he started with financial injections provided by his father, ceased to exist as an independent company when it was taken over by a larger domestic IT company. Henry Chan did not resist this takeover as he preferred to put his energy into his China ventures. However, something even more exciting came up when his cooperation with Australian and Chinese Malaysian university friends in Klang Valley, the Silicon Valley of Malaysia, led to plans to expand to Europe and the United States. For this purpose and for enhancing competitiveness, they attempted to acquire international certification for their products and services. All in all, this Western-Asian joint venture is an exemplary case of the increasing cosmopolitan outlook and professionalisation of entrepreneurs of small and medium firms.

\section{Relocating Business After Failure: An Analysis}

Singaporean SMEs may venture into China, combining both the 'typical Chinese' and the 'Singaporean' way of establishing contact. They may enter in the slipstream of family relations and networks, following government-sponsored trade missions or because of the relocation of their main clients. Sometimes, they may utilize all of these opportunities at the same time, and fail anyway, as Case 3 will illustrates.

\section{Case 3: Mixed strategies}

\section{Templex, a Fashion Trade Company}

Mr Johnson Lee, Singapore born, descends from a Hong Kong business family. He started working life at a young age in one of his family's trade firms, went to night school to obtain a degree in marketing and joined the fashion industry working for a foreign MNC in Singapore. In the mid-1990s, he ventured into this industry on his own. Ever since, he has sold European fashion products, famous brand names, on the Singaporean and Malaysian market.

\footnotetext{
53 Fieldnotes, August 2000 and May 2004.
} 
With only three employees, he established a joint venture with relatives in Hong Kong. Together they entered into a distant-kin partnership "just across the border" in Guangdong and further away in Shanghai. The partnership was managed by Johnson's Hong Kong family who made wrong investment decisions. The China venture failed within three years and up to the present day Johnson is not sure what exactly went wrong. "China is too big of a game," he concludes, "one is not familiar with the market and it is difficult to manage from a distance; it is the 'big unknown"".

After the China venture, his business also had to weather the storm of the Asian Crisis which came down hard on the fashion industry. His business survived thanks to the support of a good old friend in Singapore and thanks to family in Malaysia who helped him get established in Kuala Lumpur. At present, he operates through two distributors in Malaysia who were introduced to him by reliable customers. He enjoys working in Malaysia as the business culture is similar to Singapore, he explains. But there are also differences. Malaysian partners and employees lack the urgency that Singaporeans usually display. They are more complacent and emotionally involved with their work. Religious differences may throw up challenges for managers, Johnson remarked, like one of his sales girls who refused to accept alcohol-containing perfumes in her assortment as she claimed to be a Muslim.

While taking more and more business to Malaysia, Johnson summarises his lessons from the China failure: "Better to keep things formal where rules are spelt out ... Family businesses rarely work, the company usually collapses when the decision-making process is kept in one hand." ${ }^{, 54}$

With tales of bankruptcies in China flooding into Singapore business life and with even GLCs failing, many Singapore Chinese SMEs shy away from investments in mainland China. For some, the experience of a business failure discourages further ventures into China and even into foreign countries altogether. Mr Yap took his plastics manufacturing firm to China only to find his Chinese partners squeeze him out of a promising business deal in the Middle East. ${ }^{55}$ Others regard a failure more as an asset than a drawback and use their experience to direct business ventures into new areas that prove to be more successful. Henry Chan down-scaled his involvement in the Shanghai joint venture when he ran into problems with the Chinese bureaucracy - without pulling out of China completely. He understands that business opportunities are still huge, but when they fail to materialise, the venturesome spirit of the young dotcom entrepreneur ventures into new fields. With the global market on his mind, he enters transnational business space in a transnational partnership - located in Malaysia.

Throughout the interviews, Malaysia has emerged as the refuge of many Singaporeans who encountered problems in China. Mr Joy, owner-manager of Wang Sound, a Singaporean music and movie tape distributor, lost much money when more stringent import rules affected his trade in illegal copies. His mainland Chinese partners demanded the payments be delivered according to the contract he had signed, although he was unable to sell the merchandise on the Singaporean

\footnotetext{
${ }^{54}$ Interview 2003.

55 Interview 2002.

Dinger
} 
market. Ever since, Mr Joy has declined repeated offers to enter China again: "There is a history of Chinese fighting Chinese and the battle continues", was his brief diagnosis of the Chinese market. Instead, he expanded business in Malaysia because the formal contracts he established with partners - all personal friends of his - are respected and implemented to the letter. Frequently, Malaysian contract law, based on the British legal system that survived de-colonisation in many former British colonies, is understood as an important advantage and, at the same time, a binding factor for doing business in countries with a common British colonial past.

On the other hand, Malaysia is not a comfort zone for everybody. Some of my informants reflected on the strained political relations between Singapore and its larger neighbour which go back to the 1960s when Singapore was evicted from the Malaysian Union. "They still treat us like a colony", complained a successful agrarian entrepreneur from Singapore who relocated his business from Malaysia to China many years ago. Others pull out of Malaysia in search of bigger markets or out of frustration with the economic policies that hinder ethnic Chinese progress or because they regard Malaysia as a backward country. $\mathrm{Mr}$ Wah, a furniture manufacturer with factories in both Singapore and Malaysia, confided that he turned to Thailand: “... good for smaller firms, not as risky. You can invest small money, labor is cheaper than in Malaysia.".56 And, finally, there are many Singaporean businessmen who establish coalitions with counterparts in Hong Kong to smooth their way into China. Mr Joe, a packing-material manufacturer who traded with China, refused to take his production there himself because he thought that business people from Hong Kong were much better equipped to invest in China: "Hong Kong understands China better than us. In China they say yes but do 'no'... you can lose everything". 57

\section{Conclusions}

The number of Singaporeans expanding their businesses to China has clearly increased since the 1990s. The new generation of Singapore entrepreneurs is attracted to China because they are looking for new markets, product diversification and low-cost production sites. To enter China in a way that avoids risk, they establish co-operative ventures with private firms, state-owned companies and foreign MNCs based on mutual interest. Although these entrepreneurs may entertain affective linkages with ancestral villages and relatives in mainland China, these ties do not play a leading role in their business decisions. There is no doubt that business ventures into China are subject to capitalist reasoning. However, the capitalist orientation of the young generation of Singaporean businessmen may also explain why China is not the single best place for Singaporean Chinese to invest. From a macroeconomic perspective, it is a very promising market due to sheer numbers (of both potential consumers and labour), but the microeconomic perspective often teaches otherwise. China is difficult to penetrate, as the multi-layered state bureaucracy requires cautious handling. The internationally less experienced

\footnotetext{
${ }^{56}$ Interview 2002.

${ }^{57}$ Interview 2002.
} 
Singaporeans may not be well equipped to deal with the complexities of doing business in China. Ethnic ties may facilitate a smooth entrance into the country, but often seem to be one of the manifold obstacles that ethnic Chinese investors encounter in China and that lead to failure. Doing business 'the Chinese way' may result in a disenchanting experience of mainland Chinese partners demanding contracts to be fulfilled to the letter, whereas doing it the 'Singapore way' may end in the troubled waters of corrupt governments and distrustful business relations.

The second and third generation of ethnic Chinese - born, raised and educated in Singapore - are often not sufficiently aware of the changes that the SingaporeChinese identity has undergone during the last forty years of nation building in the city-state. Their image of the Chinese identity is characterized by two cardinal mistakes. First, they think that their personal resources establishing Chinese identity are identical with the resources of the older generation of Singapore Chinese. Second, they think that mainland China has remained the same as it was when their parents maintained connections with their place of birth or ancestral village. However, there is a gap of a few decades since the older generation was actually involved in mainland China. In the meantime, Singapore has developed into a modern nation state with a British colonial history and a multicultural present. Memories of a Chinese past have generated frozen images and stereotypical representations of China and the Chinese identity in the Singaporean imagination. The idea that looking Chinese, speaking the language and sharing 'Asian values' constitutes a sound basis for business success has turned out to be rather naive. Societal transformations in both China and Singapore render part of the social capital which Singaporeans presume to possess inadequate and redundant in the present situation of doing business in mainland China.

These few examples illustrate that the Singapore government was overly optimistic to expect that the transplantation of the Singapore economy to the Chinese mainland would solve the problem of too tiny a home market by way of an 'external wing' or even a 'Singapore II'. Cultural affinity, a shared language, an understanding of business practices and even government support turned out to be insufficient guarantees for lasting success. As Johnny Lim, a Singaporean iron and steel producer said: "China is very Chinese, by comparison Singapore is not Chinese at all" ${ }^{58}$ For Lim, the awareness of the cultural differences between the two countries resulted in successful deals with Chinese partners. For others, the same awareness became the reason to pull out of China. "We do things different here in Singapore", has been a much quoted statement in this context.

Learning by experience that Singapore Chinese identity represents a disadvantage instead of an advantage in China contributes to a changing attitude vis-à-vis the ethnic Chinese in Malaysia, their closest neighbours. Many of those who delete China from their foreign venture planning turn or return to Malaysia instead. The relationship between the Singaporean and Malaysian Chinese is ridden with problems that reflect the tense relationship between both nation states. However, Malaysia also represents a comfort zone to turn to in order to recover from business failures in mainland China and to reconsider business strategies for the future. Because of the close relationship comprising a shared past and a separate present, of

\footnotetext{
${ }^{58}$ Interview 2003.

型 Springer
} 
love and hatred, similarities and differences, acceptance and rejection, the social capital of both Singapore and Malaysian ethnic Chinese is well suited for joint business ventures. However, Malaysia seems to be only a temporary comfort zone. Once the wounds caused by an unfortunate China venture have healed, Malaysia turns out to figure only as a stepping stone to business start-ups in Australia, Europe (in particular the United Kingdom) and the United States.

Acknowledgements The data collection was implemented under sponsorship of the NWO-related Aspasia-programme titled "Organizational Culture in Transborder Region", which was coordinated by the author in 2000-2005. The author wishes to acknowledge the contribution by Dr. Helen Kopnina who collected the case studies of small- and medium-scale Singapore-Chinese enterprises in the period of 2002-2003 as part of the Aspasia programme.

Heidi Dahles is full professor in organizational anthropology at the Department of Culture, Organization and Management of the Vrije Universiteit Amsterdam. She obtained her Ph.D. in 1990 from Radboud University Nijmegen and held positions at Tilburg University, the International Institute of Asian Studies (Leiden) and the University of Amsterdam. Among her recent publications are "Managing Cohesion in Transnational Organizations" (with Lineke Stobbe), a special issue of Culture and Organization (London: Routledge, 2004) and "The Re-Making of Boundaries in Asian Multinational Organizations" (with Loh Wei Leng), a special issue of Asia Pacific Business Review (London: Routledge, 2005; also published as an edited volume in 2006). Her research interest is in organizational networks and processes of identity formation in Southeast Asia. 